\title{
The effect of the American stereotypes in the formation of the middle class Greek family image in the post-war print advertisements
}

\section{El efecto de los estereotipos americanos en los anuncios impresos de la posguerra y la formación de la imagen de la familia griega de clase media}

\author{
JOHANNIS TSOUMAS \\ Hellenic Open University/ Technological EDucational Institute of Athens \\ iannis33@hotmail.com
}

Recibido: 12 de junio de 2014

Aprobado: 12 de junio de 2015

\begin{abstract}
This research aims to capture the value of the first, mass-produced, women's magazines advertising in post-war Greece regarding the identification, the analysis and the morphology of both the middle class Greek family image and ideal.

With the help of rich and unexplored material of that era found in photo albums, folklore or museums, and by looking at the political, economic and social history of the country, we will initially attempt to capture the real characteristics of the urban Greek family, in the way they were reshaped after the end of the destructive World War II.

We will then explore the grounds on which the print advertising in the country seemed to be drastically affected by the US advertising standards that dominated the global landscape of post-war trade. Through this practice we will discover that the post-war Greek family started to be presented through the American stereotype in which it was not involved at all in reality. The presentation of mother / wife / homemaker, the role of father / husband as well as the sophisticated image of children seemed not merely to abstain from the daily routine of the average Greek family image, but to oppose to it, both aesthetically and practically.

But how did the - mostly - female readership take the fabulous display of the 'new Greek family' which was based on the American standards and what was the final effects of this type of advertising on the post-war average Greek family consumption behaviour? Did it work effectively or it simply constituted a comical and silly manner which endangered the new products consumption? All these questions will be answered with the help of much photographic/advertising material found in many rear women's magazines of the era, and some valuable, though small in volume, literature.
\end{abstract}

Keywords: print female advertising, post-war Greek family, American advertisements, consumption.

Tsoumas, J. (2015): The effect of the American stereotypes in the formation of the middle class Greek family image in the post-war print advertisements. Arte, Individuo y Sociedad, 27(3) 395-412 


\section{Resumen}

Esta investigación pretende evaluar las primeras revistas publicitarias para mujeres producidas en masa en la Grecia de la posguerra, a consecuencia de la identificación, el análisis y la morfología tanto de la imagen familiar como de la imagen ideal de la clase media griega.

Inicialmente, vamos a tratar de captar las características reales de la familia griega urbana, con la ayuda de valioso e inexplorado material de esa época encontrado en álbumes de fotos, folclore o museos, y la observación de la historia política, económica y social del país, teniendo en cuenta la forma en la que ésta fue reformada después de la destructiva Segunda Guerra Mundial.

A continuación, analizaremos los fundamentos por los que la publicidad impresa del país pareció ser afectada drásticamente por los estándares de publicidad estadounidenses que dominaban el panorama global del comercio de la posguerra. A través de este ejercicio, descubriremos que la familia griega de la posguerra empezó a ser presentada mediante un estereotipo americano con el que, en realidad, no tenía absolutamente nada que ver. Se presentaba a la madre/esposa/ama de casa, al papel del padre/marido así como a los niños, con una imagen sofisticada que no solo se abstraía de la rutina cotidiana de la familia griega corriente, sino que se oponía a ella, tanto estética como prácticamente.

Pero, ¿cómo se tomaban las - en su mayoría - lectoras esta fabulosa exhibición de la 'nueva familia griega' si estaba basada en los estándares americanos? Y, ¿cómo afectó este tipo de publicidad en la conducta consumista de las familias corrientes griegas de la posguerra? ¿Funcionó eficazmente o simplemente constituyó un cómico y absurdo modo de exponer los nuevos productos para su consumición? Todas estas preguntas serán contestadas con la ayuda de material fotográfico y publicitario encontrado en algunas revistas de la época para mujeres, y algo de valiosa, aunque escasa, bibliografía. Palabras clave: publicidad impresa dirigida a mujeres, familia griega en la posguerra, publicidad americana, consumo.

Summary: 1. Introduction, 2. Family and historical / social context, 3. A brief look at the american economic power attainments, 4 . Women and family magazine ads in the U.S. and Greece, 5. Morphological and social analysis of advertising, 6. Conclusions. References. Endnotes.

\section{Introduction}

The print advertising and all the more so the popular women's magazines of the era of our interest, has been an important indicator, albeit secondary, of overexertion that Greece made a few years after the two wars (World War II 1940-45 and Civil War 194549), during the period of reconstruction, to be reborn through industrialization. This finding thus leads to the valid conclusion, that Greece, although in an underdeveloped region of southern Europe, which in the following decade fueled the industrial North with unskilled labor, reached, even in politics, the high production and consumption level of respective countries (Kalfopoulos, 2008: 5,6).

Another observation concerns the typological understatements of that era: the majority of ads were either based on a person or they directly advertised the product, in one rather prolix logo, compared with today's criteria, while the connotations and abstraction were rather unfamiliar concepts to remarkable advertisers. At the same time there were apparently some "threads" which, by today's standards, would plough not only into the "political correctness" but also into gendered stereotypes. The family was one benchmark of great importance in the semantic interpretation of these stereotypes, as well as the way in which it was viewed and promoted, it being seemingly inversely proportional to the social conditions prevailing in the 
young middle class, in the consumer dynamics of which this kind of advertising was addressed. But what exogenous stereotype was behind this new advertising campaign aimed at subjecting the average Greek family to unprecedented consumer frenzy? To what extent could the pattern of traditional, urban Greek family have been distorted through this new outlandish invasion of new lifestyles and consumption? At first, we shall attempt to make a reference to the average Greek family of the immediate postwar period through the historical/social context of that time, and will proceed to highlight the importance of women's magazines of the era and the ads posted in them, focusing on the family. Finally, through analyzing some types of ads we will focus not only on how they were fashioned, but also on the importance of the roles of the Greek family key players, as such were staged to increase the consumption of goods, whether imported or not.

\section{Family and historical / social context}

The postwar period in Greece evolved at different times and was diversely experienced by people who came from the tempests of the 1940's. On the one hand, large-scale changes occurred, such as urbanization, industrial development and immigration and, on the other hand, reactions were developed within a divided society that often refused to negotiate with its past and was unable to rationalize its dilemmas such as the Cyprus case or the political prisoners issue.

For the first time in the period $1952-63^{1}$ a process of urbanization of the Greek population occurred, where the ratio of rural-urban sector was reversed in favor of the latter, the main site of absorption being the urban area of Athens. Moreover, the mass movement from the countryside to cities was accompanied by the rapid growth of foreign migration. The structural changes that occurred were recorded primarily at work (forms of employment), at consumption and government measures to stabilize and develop the economy. The development of communication networks, the spread of cinema, and the emergence of tourism brought into contact wider sections of society with the lifestyle of industrial society. It was during this period that the then government authority of the country turned its interest towards the developed Western countries, mainly the US which had already made felt its military presence in the Mediterranean region, asking for help and support. It was not late before the new images of the lifestyle of Western societies introduced in Greece which were peculiar of a new model of consumption, began to influence the Greek buyers, especially those belonging to the shyly emerging middle class ${ }^{2}$ (Tsoumas, 2007: 13, 14).

Within this sociopolitical context, the family was the basic cell of the newly emerging middle class as a haven of healthy emotional support, financial security and personal care of the family group members. Then the marriage lasted "for life" and the perception of the inextricably tied couples who were planning their lives according to the duration was taken for granted. For the traditional family of two spouses and their children, marriage represented a holy and steadfast institution which guaranteed not only security, but also social reputation and fertility. However, it should also be noted that the classical model of the family, was not nonnegotiable on its composition, and could include other relatives such as parents, grandparents, or even uncles, aunts and 
cousins. This type of extended family was often called the family of three or four generations because it contained the three generations of parents, grandparents and children, who usually lived, if not under the same roof, at least on the same street or in the same neighborhood where their regular contacts were established.

Apart from the traditional, narrow reasons according to which the closely related persons used to form the profile of an extended family, there were also practical / economic ones. Grandparents contributed at home both with their pension and raising grandchildren while the parents had, at the same time, secured apart from a substantial financial contribution, the safe and healthy upbringing of their children. For the children themselves the profit was double since they had their four closest people deal with them and care for them, sometimes even to the point of exaggeration. (Papaoikonomou, 2013: 180).

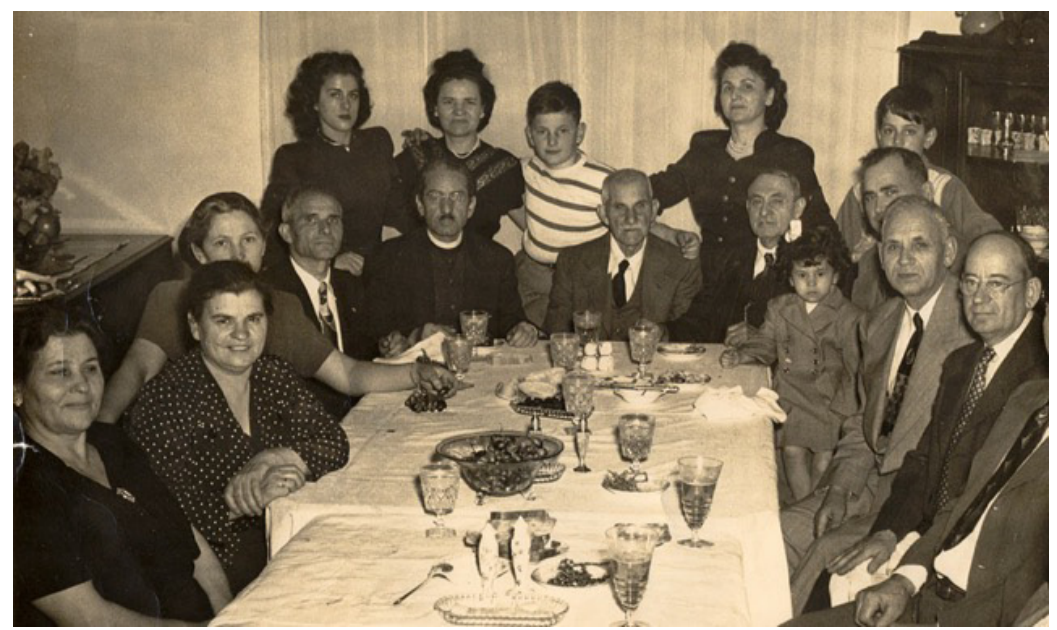

Figure 1. Greek middle class extended family photograph in a typical family party, Athens, 1950s.

For both the peasants who swarmed into the major urban centers due to urbanization, and the working class or bourgeoisie the classic model of family was considered very conservative because its features remained patriarchal. For this reason, it was assumed that both the fixed values and attitudes that it developed should be handed down to future generations intact (Moussourou, 1999: 35). More specifically, the stereotype of the husband - father was sacrosanct and non-negotiable. This diptych was undoubtedly the head of the family, as it was he who took the decisions and had overall responsibility for all aspects of the whole family. He represented the family in the outside world, struggling to feed them, to ensure their interests and protect them from any attacks (Kogkidou, 1995: $85-86$ ). When the family car broke down it was him who would repair it and If a strange noise sounded in the hallway it was him who would look for what had happened. So, as he was the dominant male member of the family and its symbolic head, he was usually the one who would ultimately impose discipline. Many children of that time still remember their mothers' usual "threatening" phrase: "I will tell your father" or "when your father comes home, you 
will see what has to be done". As he was at work for the largest part of the day, he would always employ his mind even in the evening when he would be back home. However, at that time the father figure was generally assumed to keep children at a distance sentimentally as from both parents children knew the fewest about him. All these are of course quite different compared to the patriarchal families that characterized the Greek postwar province. There we will meet a father stereotype who would cause more fear to children than respect, i.e. a hard - authoritarian and unapproachable father and husband as well (Christoforou, 2012: http://www.ygeiaonline.gr/index. php?option $=$ com_content\&view $=$ article\&id $=7564$ :rolos-father\&catid $=157$ :relations hips).

The role of the woman on the other hand - as we will see more analytically in one of the following chapters -, was coordinating and connective as a symbol of love that used to bind family and complement the role of man. Despite the allegiance she presented to her husband, her contribution to the survival of the family was very important (Tsaoussi, 2006: 27). For example, her role in the education of children, the provision of household and general financial management of the house was fundamental (Pantou, 2006: 17).

But especially during the 1960's the parallel continuing presence of women in the labor market was strongly associated with the rise of educational level, a rise that took place at a faster pace than that of men. In any case, both the change in the economic functioning of the family and the paid work of women constitute key factors shaping the structure and dynamics of the average urban family and contributing to the dependence of its stability and consistency upon individual abilities and desires (Panselina, 2003: 6).

In the postwar Greek family one member, the child, had acquired a leading role as an objective which the marriage and creation of family relied upon. The postwar hardships in material and intellectual goods created an excessive focus on efforts to educate children, a pervasive anxiety and pressure on their performance at school and it is no wonder that success of children was closely linked with the promotion and the psychological uplift of parents themselves.

\section{A brief look at the american economic power attainments}

As economic historian Alan Milward wrote: "the United States emerged in 1945 in an incomparably stronger position economically than in 1941". By 1945 the foundations of the United States' economic domination over the next quarter of a century had been secured. This may have been the most influential consequence of the Second World War for the postwar world (Milward, 1979: 63).

Trying to rebuild a stronger future on the economic debris left after the war, American society became more affluent in the postwar years than most Americans could have ever imagined before or during the war. Public policy, like the so-called GI Bill of Rights passed in 1944, provided money for the war veterans to improve their education level by attending University or College classes, to buy or to construct new houses, and to invest on farming. The overall impact of such public policies could not be easily calculated, but it certainly contributed in returning veterans to 
ameliorate themselves and to begin forming families and having children in really high numbers (the famous 'baby boom').

On the other hand, in terms of productivity development, the changes were enormous. The rapid growth of automation technologies aided manufacturing, while wholesale and retail trade benefited from the new highway systems, distribution warehouses and material handling equipment (Bjork, 1999: 67), oil became the basic form of fuel, replacing coal in many crucial applications, especially in locomotives and ships and unemployment was severely reduced.

However, not every single American citizen took equally part in these improving life chances and consequently in the growing economic abundance. Both the image and reality of overall economic well being - and the upward mobility it provided for many white Americans - was not lost on those who had largely been excluded from the full meaning of the American Dream, both before and after the war. As a result, such groups as Afro-Americans, Hispano Americans, and American women became more aggressive in trying to win their full freedoms and civil rights as guaranteed by the Declaration of Independence and US Constitution during the postwar era.

In order to really understand what went on during this prosperous period often called The Golden Age of Capitalism, it is important to look at the rate of profit. The global economy would create conditions for very high investment rates, high output growth, low inflation - and surprisingly — low unemployment (Marglin, 1992: 2). The Golden Age trends in accumulation, profits, investment, output growth, and employment are associated with particular historical conditions. Therefore, they laid the basis for many institutional arrangements that urged capitalism toward the mixed economies of the 1950s. Further more, the threat of communism and the US victory in World War II established the terms of the Pax Americana. Internationally this meant an upgraded role for the US, which had already been the main creditor of World War I.

After World War II finished and while the American social / political and cultural map, following the economic growth of the country, presented many significant changes, the institution of the family remained strong, intact and inviolate symbolizing the traditional comforts of home which was affiliated with the joys of family life. This basic social condition was not considered insignificant by the US advertisers who were trying to discover new targets for the promotion of different types of products which were produced in astronomical speed at the time. Advertising started to exploit all this new social and economic change in favor of the new, dynamic national or multinational companies and even whole industries, including television and commercial aviation, which started to spring out rapidly in the country. The interpretation of this status quo of well being in commodities and consequently in advertisement promises, inaugurated a new era of culture the basic core of which was, of course, the American family, the most important consumers target, according to the advertising agencies of the time.

\section{Women and family magazine ads in the U.S. and Greece}

The abundance of goods and, consequently, advertising can be semiotically interpreted as the ultimate expression of prosperity, happiness and balance of the 
average American family whose basic stereotypical members (father, mother) were highly idealized. The male stereotype seemed to still prevail both in the simply social, and in the deeper conscious field of the Americans, which became readily perceived by the advertisers. The decisive and dynamic husband / father characterized not only by his intense professional lifestyle, but also his traditional supporting role in the family (primarily in economic terms as usually his professional obligations left him aloof to the family duties which would normally, $\operatorname{cog}$ his wife's shoulders) was the main pivot of most advertisements related to the specific consumer group.

In the decades that followed, the US governments' intention to convince people that "despite the unfortunate fact" of the emerging U.S.S.R. power, the country was one step ahead (which was interpreted into an anxious attempt to overproduce military equipment and systems, in general), found application in the fields of consumption, and - by extension - advertising. Characteristic examples are the national symbols of the 'nuclear cloud', but also the American nuclear bomb's exterminating speed, that is two important technological and cultural elements of the then American power which, transferred to the fields of mass production and advertising, acquired mythical significance. The post-war American advertising seemed to manage significant historical events in a utilitarian way, using certainly mass consumption and the corresponding technological achievements of industry such as cars and appliances as inciting gears (Heimann, 2003: 4-5). At the same time, scientific breakthroughs and aesthetic development seemed to affect both the less economically powerful classes of the country and Europe, with products that would later become the benchmark for western civilization, such as plastics of a mainly specialized type of production (nylon, Lycra, Teflon, Plexiglas, etc.). Mass production as well as the easy automation devices absorption by the large consumer masses, travelling by plane, advances in electronic technology and the space exploration were some of the unique achievements of the era that dawned after the Second World War.

As in the postwar US, so in Greece ads had always reflected the mood of society to forget its recent, painful past and to look optimistically to the future of hope, to taste new products that once had been denied or were completely unknown. The benefits of peace seemed to coincide with the abundance of numerous imported, as well as, domestic, commercial products that represented the free and ever-growing competition of Greek firms.

The role of women in the US according to the up to then mighty manliness stereotype had often been supportive in the family. It was not by chance thus that women in the postwar period in the country became the main focus of most advertising-related products referred to the family, the image of whom appeared highly embellished and beautified. The American advertising, especially in the 1950s, was not just indicative of a convincing sales strategy with a focus on the woman and her family. At the same time American ads were meant to be exemplary proposals of social mentality of decency under which the average American family should be brought to live in the conservative, conformist spirit that the ads called for (Sivulka, 1999: 235-237). This was another ingredient in the successful recipe of the advertising myth which we can now see and experience in the mass consumption culture of our time. 
In Greece, especially during the pre-television era, i.e. before the typical appearance of television in 1966 and its substantial expansion in the 1970's ${ }^{3}$, the printed press - primarily newspapers and, incidentally, magazines - seemed to invade in an ever-increasing manner the Greek households. The "consumption" of the content of these publications of entertainment and information to the buying public began then to be a daily, and at the same time, necessary reality. Advertising as a mythical mirror image of the economic / consumption system of the country found fertile ground in the pages of these publications and often followed the legacy of American standards to shape its aesthetics, but mostly semantic view (Cheretakis, 1977: 20-25). The women's magazines were the first forms of printed material with semiotics on gender which grew rapidly and this can hardly be regarded as a coincidence. Such publications typically included lightsome articles for the wife, home and family. Their partly closely-written color pages were full of social, dramatic, emotional, historical novels of fascinating plot and content, as well as vignettes, exotic stories and many of them would also include famous photo-romances, which were a primary form of the current TV serials. Through these, women were presented as "romantic, helpless, irritable creatures, too emotionally dependent on men for support and guidance." The magazines had of course a much longer life than newspapers, so the advertising messages were much lengthier and more efficient. Some of the most popular women's magazines of the era were: Domino, Vendetta, Thissavros, Eikones ${ }^{4}$, Ergocheiro, $O$ Tachydromos, Gynaika, Pleksimo and of course the legendary Romantso whose sales had gone as high as 280,000 sheets weekly 5 .

Emphasizing on women who, depending on each case, seemed to perform different roles, assuming sometimes the role of wife, some others that of mother, or of housewife or sometimes all three together, the image of the Greek family made its dynamic appearance in the early advertisements in these magazines which were considered as the ideal venue for hosting these messages. But what was true about the actual position of women in the Greek postwar society? How did they become the centerpiece of the advertising campaign in the postwar Greek consumption? The Greek mother/ wife / housewife had always been a weak, but also dynamic stereotype, because she was always considered a "queen" at home, but "nothing special' out of it. The "theory of separated spheres" on which the public sphere rightfully belongs to men remained still in force as 'unwritten law' before and after the Second World War. According to this theory the public action of women was not prohibited, but it was supposed to be in line with their obligations in the private sphere: they did not have to endanger the unity of the family, by distracting the woman from her "main" duties. Additionally, under this theory, the "natural" position of women was their restriction in the private sphere where they were to act as mothers and wives. In the private sphere, the man could also perform his "natural" prerogatives as the head of the family. As both men and women were still being socialized by learning the traditional division of roles (male $=$ supplier and woman $=$ housewife) and the traditional division of space in private - female (house) and public - male (market), the tasks of household activities and childcare were not equally distributed between the sexes. Despite the fact that Family Law in all modern states required full gender equality within the family, housework and childcare were still the primary responsibility of women, as indicated by the relevant sociological research. 
This absorbed great deal of the time and energy of women, thus leaving them less room to seek professional opportunities, to compete with men on an equal footing for a place in the labor market and to ensure their economic independence, and consequently their power and influence within society (Tsaoussi, 2012: http://old.phs.uoa.gr/ ahatzis/ SGH08.pdf).

This entire theoretical dimension of only one part of the so-called woman question was seemingly perfectly fit in the social position of the Greek women after the Second World War. Housewife, wife and mother, the Greek woman of the rising middle class as well as of the lower class, was rarely getting away of this tripartite emblem of the long scale of moral values that she had been taught almost from birth. The concept of "honor" which was always identified to this often fatal, karmic role was the bridge that connected the moral of the female sex and society, and ratified the status of the Greek woman. Furthermore the "inviolability" of this "honor" was considered a precondition for the success of this triple role within the family stereotype. The Greek mother, wife and housewife of that period should be simple, accessible and faithful to her children and husband, effectively responding to the needs of the home and family, a housekeeper in managing the family budget and thus thoughtful and careful in how to spend the money, dynamic in difficulties, pleasant in social contacts, stylish with an elegant appearance. In the pre- capitalist, post-war Greek society and unlike the male character of many, mainly public, areas (cafes, football stadiums, police, army, the Parliament), the house was for the woman her undisputed realm. There, she could perform all these tasks which were translated into a type of pro bono work, except that it was a full-time employment. The work of the Greek woman in the house was only recognized as being "real" quite a few years later. Nevertheless, this work did not entail lower social status compared to paid employment. Often, the career was a taboo for women of that time and especially for the married women. Besides, the labor market in Greece was divided by gender, in the sense that professions were divided into "male" and "female" ones. The female occupations had much lower wages, fewer opportunities for professional advancement and less social prestige than male occupations. The majority of women were mainly employed in unskilled and semi-unskilled manual jobs or in low-level, white-collar positions. The senior management positions, such as bank directors, chairmen or CEOs of companies, and prestigious professions, such as doctors, lawyers, engineers or academics, seemed to be a purely masculine space.

As most domestic advertisers had already discovered the recipe for success promoting advertising messages based on the social value of the family in the US, and being aware of not only the importance of the family ideal for the Greeks but also of the crucial role of the Greek housewife, they attempted to introduce an identical model in the corresponding Greek advertisements. But was that effort proportionate to the reality experienced by the average Greek family in social, aesthetic, economic and moral terms? Did such type of ads look like reflecting the true - even embellished - person of postwar Greek family and its essential needs? Or was it merely a corrupted and distorted picture of the true image since it did not consider the key morphological, moral and cultural characteristics? 


\section{Morphological and social analysis of advertising}

Looking carefully at the ads on family of the two important decades that followed the Greek Civil War, we can identify several coincidences and similarities with their American counterparts. After such a devastating war, it was clear that the necessity of advertising to an "extrovert" and "purely Mediterranean" people who had already had a lot of frustration from the four hundred years of the Turkish occupation and, at the same time a huge appetite for consumption greater than that of a bulimic elephant, was imperative. Delayed Greece finally "discovered" the full qualities of advertising during the 1950's in a speed of light way. The country seemed to start worshiping every version of black and white or color, print or radio, painting or photographic advertising type; this way advertising managed to leave its trace in the collective memory of the Greek family and to be associated with its concept.

For the historian of the future though, a complete record of ads would be suffice so as to draw safe conclusions about the character of the Greek family of that era, its real and artificial needs, its harmful or harmless passions or its pragmatic utopian desires and of course its degree of intelligence and its resistance, to a, many times, American sense of humor.

The majority of ads that prevailed during that period were those who addressed directly to the 'secure' Greek family target group, rather than to individuals such as women, men or children of particular age groups or classes. More specifically, however, the ads which - according to American standards - included the participation of all family members for products which could be used by all family members, were the most successful. So advertised products related to the house cleaning or the body sanitation, clothing, food, entertainment (in the home context), but also the use of public goods such as electricity or water, were the most characteristic of the time.

From a morphological point of view, the Greek print ads of the 1950's were almost peculiar to the American model, as the conservative logic of American consumer society imposed certain ways of advertising performance, particularly those related to individuals and social institutions.

So in that decade we will see that photography was not the main morphological center of the Greek print advertisements, as it was by itself a direct form of information for which the Greek reading / general public was not yet ready. Most advertisers presented the family and its surrounding area - always according to the American standards - through drawing and painting forms and / or sketches, color in many cases, trying to give in this way the ads the aspect of illustrated fairy tales (Bettelheim, 1995: 21). 


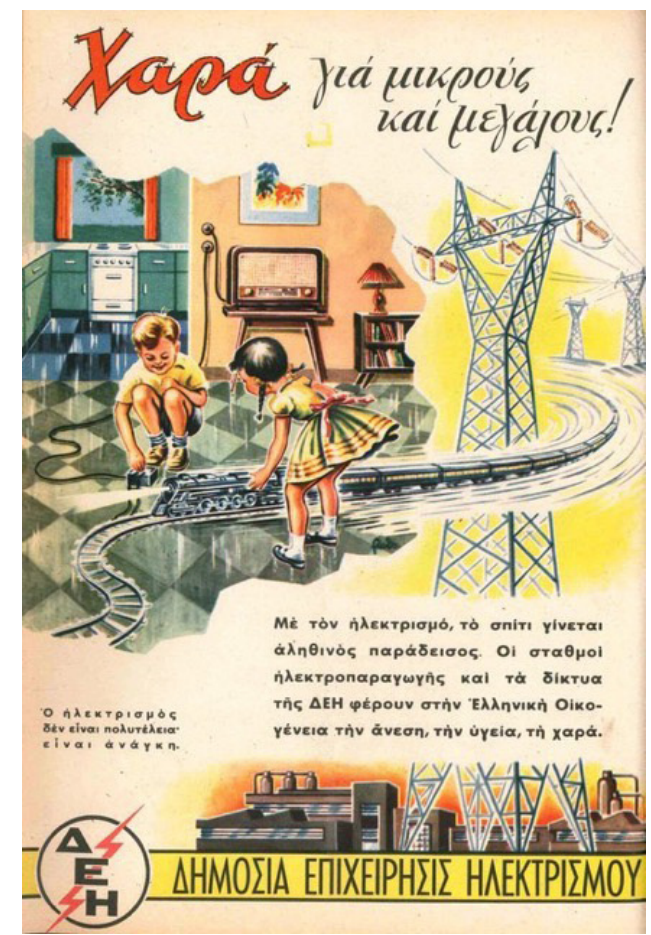

Figure 2. A characteristic print ad in color drawing form, 1957.

The vivid colors and patterns of people and objects in bold outlines, constituted another key point in our analysis as they referred to the functional value of posters of past decades, highlighting in the most ideal way both products and family as a group of consumers. There were of course cases in which the use of photography was permitted, provided, however, that it had undergone an intense process to incorporate it in the total advertisement design. It should be mentioned that the technique of lithography was very helpful in producing this type of advertising.

Instead, the ads of the 1960's seemed to eliminate this fabulous glamour and focused on the emergence of the Greek family through modernized methods of representing it, such as the use of photography and in some cases editing. The advertising companies of the time along with those which had already been established (GRAPHIS, SPOT, Ammirati Puris Lintas, Katzourakis - Karabot, ALEKTOR etc.) began to systematically form themselves by hiring graphic designers, text editors, account editors and were soon turned into "full service" companies. According to their techniques and ideas the dynamics of the photo of that period would not seek the use of color, as it was, by itself, a direct message, especially in the first years of the decade. This is why we can observe that too many of these entries were black and white (this can also be connected with the great success that the classic black and white Greek movies of this decade used to enjoy ${ }^{6}$ (Vatouyou, 2006: 251, 252). All this happened because the sultry embrace of photography by the fine arts had not made its presence felt. The painters still despised the photo without feeling threatened by it, while the 
photographers enjoyed the recognition of artistic work, without hoping that they could ever compete painting in its already frantic speculative route and especially the one that the previous decades print advertising had indicated.

As part of the morphology of the ads various persons were also displayed in any advertisement that promoted products for the average Greek family. So in the advertisements of 1950's we can witness an almost unchanged application of the stereotypes of American families with persons whose characteristics differ significantly from those of the members of an average Greek family of that era. By contrast, the 1960's required the use of models that bore the characteristics of the Mediterranean average Greek family, which made this type of ads more believable and therefore more successful.

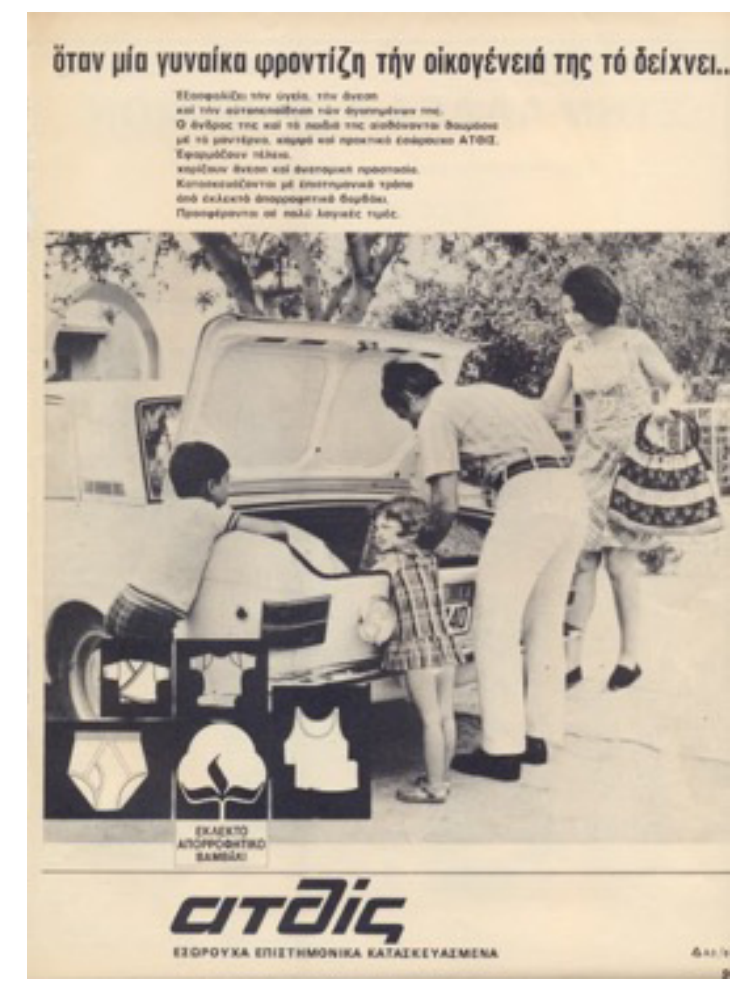

Figure 3. Models with Mediterranean features were used in this print ad, 1964.

Of particular interest are the ads from a sociological point of view as well. The importance of using gender stereotypes in shaping an advertisement was great in both decades of our interest. We should therefore focus on how the US advertisers - and by extension their Greek counterparts - exploited these stereotypes and created these promotional messages.

We observe that in many of the ads of the 1950's, the symbol of mother/wife dominated almost every advertisement. In advertisements where the family was a quorum, the woman usually stood out in some way; for example, she was placed 
higher than others. In others, she was a prominent figure who, in connection with her children, created the "atmosphere" of a healthy and happy family, even without the presence of her husband, which in many cases looked like as if it was not necessary. In this case the woman was supposed to be responsible for any need related to parenting or home, because beyond any doubt it was the woman who assumed not only the financial, but also the moral management of the family. It should be noted however that this model of family, which can be interpreted as a single parent family, did not represent in any way the Greek society, much more so the Greek family. Surprisingly enough, it was considered quite successful in terms of consumer influence.

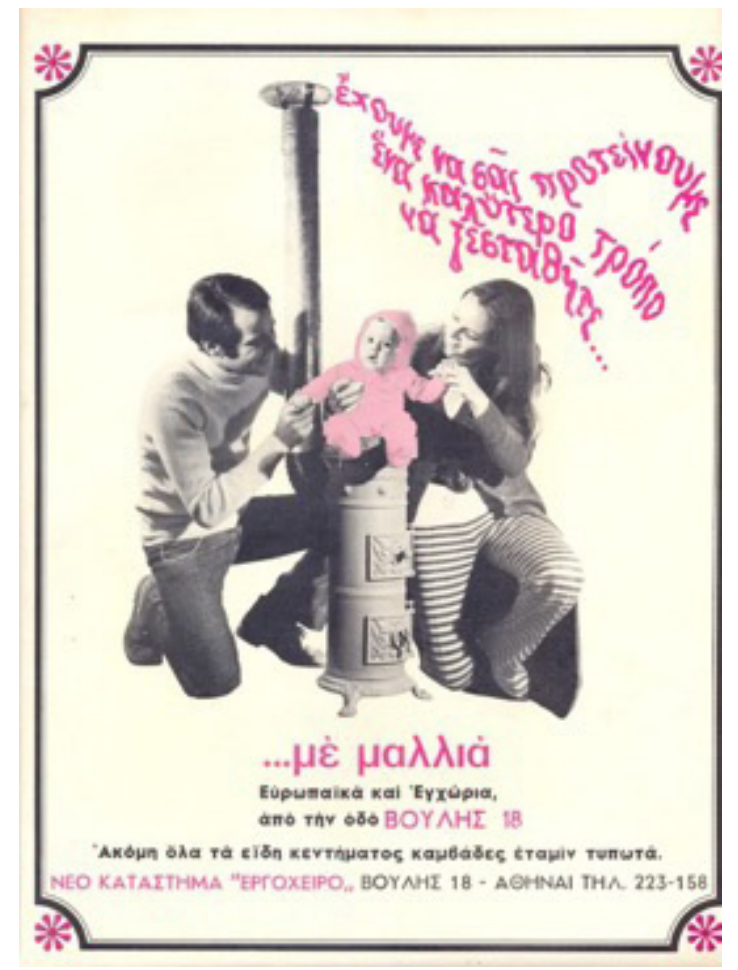

Figure 4. The American family equality concept was applied in this Greek ad, 1965.

The American social revolution of the 1960's under which the woman was released from her bonds within the marriage and in the family reached the middle class Greek family through this type of advertising. The repressed Greek woman of the 1960's seemed to be emancipated and liberated through the advertisements of women's magazines of the time, demanding a fair and equitable relationship with her husband in the family. The husband / father role was presented to be sweet and benign, with love to his wife and child, ready to offer his services for his upbringing. This was perhaps the most beautiful part, though extremely unreal, of the advertising story, and inspired thousands of Greek women readers who vainly sought such a marital relationship. 
There were, of course, ads which induced not only the characteristics of family equality, but also the feminist excesses of the American culture, which had nothing to do with the Greek reality. More as a form of revenge for the repressed decades, the ads that discredited the previously non-negotiable and strong male, marital role, probably functioned positively in the wake of the purchasing capacity of the Greek women. On the other hand, though, the emancipation feature of the Greek advertising focused exclusively on women as units, i.e. as a new, independent and self-reliant consumer cell, cut off from the fundamental concept of the family. This was quite natural as the role of the liberal and anti-conformist woman did not seem to be at all compatible with the Greek - but even with the U.S. - stereotype of the average family of the time.

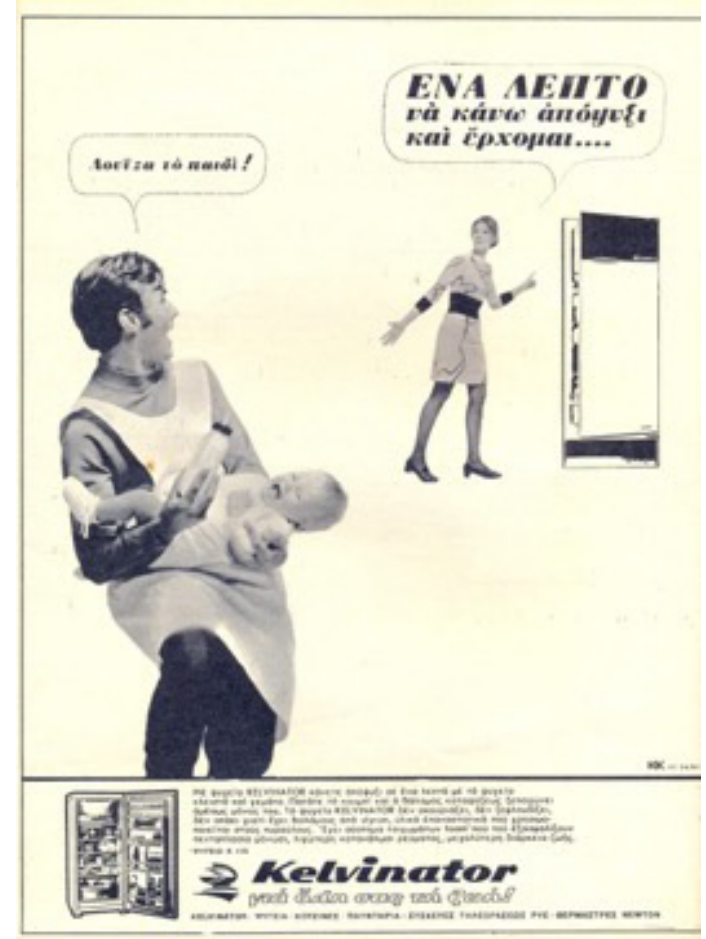

Figure 5. A characteristic print ad showing the much desired women emancipation in the family, 1967.

According to the above, children's stereotypes were similar in nature: in most advertisements children sometimes appeared in bold Saxon features, innocent, excessively fed and, consequently overweight, blond and cheeky, i.e. by following the strictly American model of 1950's. However, this type of children was essentially non-existent in the postwar Greek urban but mainly provincial societies. Most Greek children of that era brought overt signs of deprivation, poverty and hardship, that is the main features of the lower social strata of the time. Furthermore and despite all these, they still kept their originally Greek features which were totally incompatible with the idealized, rather superficial American physical lineaments. Although as we 
have already mentioned these stereotypes changed the following decade as they were replaced by a decent, Mediterranean type of models, children continued to occupy a special place in the advertisements of these magazines. The main reason was that children in the family were used as another important pole of promoting products focused on eating and clothing items, thus participating in the major consumer game of the newcomer US multinational companies to Greece.

\section{Conclusions}

If we look up the words of Baudrillard we would understand that "...advertising itself is now the most important means of mass communication, having managed not only to override the importance of media conveying and communicating it in the mass, but also to usurp it... "(Baudrillard, 2005: 146). By this logic the Americanized ads of postwar Greece which tried to capture the new reality of the average Greek family, have also succeeded to hijack the myth of the media that hosted them and create in the female readers and consumers many hopes, be they falsified or not.

As the political, economic, and cultural context of the newly-fashioned Greek reality was directly affiliated with the American imperatives in shaping a new status quo in the Mediterranean and the Balkan Peninsula, it is no wonder that a new form of advertising proposals was created according to which the middle class Greek family would rather have strongly American characteristics. Here, we have to note that the American culture, and thus consumption postwar model was established internationally, first because the Marshall Plan ${ }^{7}$ flooded Europe with American products, secondly because the US excelled both economically and technologically and thirdly, because in the context of the Cold War the US treated their superiority in cultural patterns through which they aimed to dominate towards the Soviet Union. The material culture Shows and Exhibitions organized by these two rival countries, especially the US, in order to showcase their ideology constituted one of the main themes of the era (Haddow, 1997: 212-217). At the same time, the creation of a Greek "star system" (the domestic cinema) which offered new stereotypes, evolved along with the changes observed in the messages sent by the print advertising of the time. Since mid 1950's, the print advertising became more aggressive, pushing higher and higher the threshold of the socially acceptable consumption. Especially during the 1960s consumption started to be the only guarantee of happiness in the family and personal lives of the purchasers, as it reached the point of being the most important means of personal satisfaction, social recognition and career advancement. And if the word "America" was directly affiliated with the meaning of consumption, dream, the Promised Land, myth, welfare, gender equality, happy and prosperous family life, the ads of such kind were welcome by the female readers of these magazines which de facto sold through their pages the same hopes and the same dreams that the American culture advertisements promised. Women, the most important figures of the middle class Greek family and consumption, were inextricably connected with this type of advertising which seemed to shape in a unique way the social, cultural and financial profile of postwar Greece. 


\section{References}

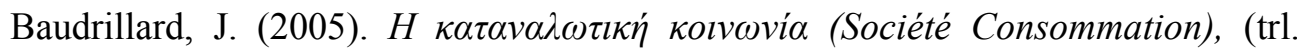
Vassilios Tomanas). Athens: Nisides Publications.

Bettelheim, B. (1996). The Uses of Enchantment: The Meaning and Importance of Fairy Tales. New York: Random House.

Bjork, G. J. (1999). The Way It Worked and Why It Won't: Structural Change and the Slowdown of U.S. Economic Growth. London: Praeger.

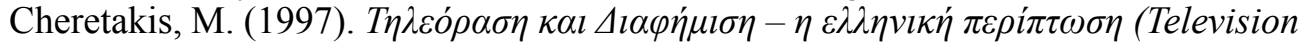
and Advertising - the Greek case). Athens: A. N. Sakoula Publications.

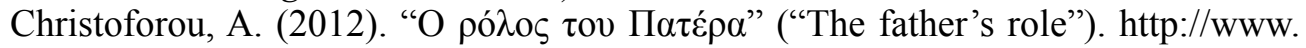
ygeiaonline.gr/index.php?option $=$ com_content $\&$ view $=$ article $\&$ id $=7564$ :rolosfather\&catid=157:relationships. Accessed 10 March 2012.

Haddow, R.. H. (1997). Pavilions of Plenty: Exhibiting American Culture Abroad in the 1950s. Washington, DC: Smithsonian Institution Press.

Heimann, J. (2003). All-American Ads 50's. Cologne: Taschen, 2003.

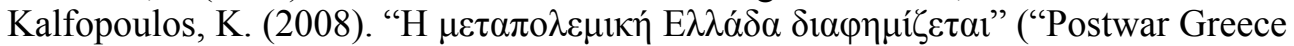
is being advertised"). Athens: Kathimerini newspaper, issue 1498.

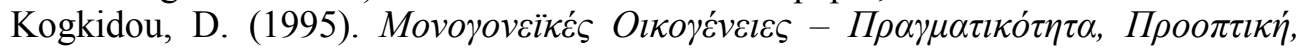

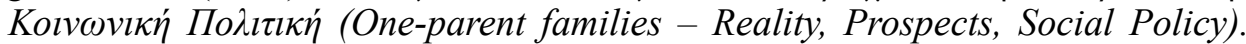
Athens: Livanis Publications.

Marglin, S. A. (1992). The Golden Age of Capitalism: Reinterpreting the Postwar Experience. Oxford: Oxford University Press.

Milward, A. S. (1979). War, Economy, and Society, 1939-1945. Berkeley: University of California Press.

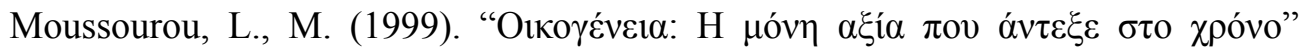
("Family: the only value that lasted in time"). Athens: To Vima newspaper, issue 1912.

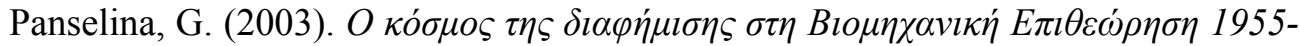

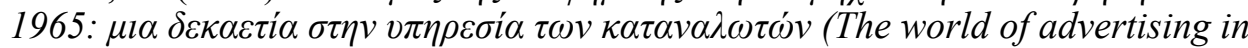
the Industrial Inspection magazine 1955-1965: a decade of service to consumers). Athens: Kerkyra Publications.

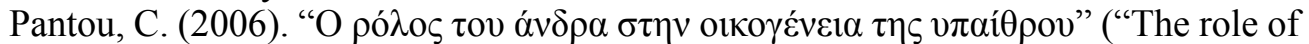
man in the rural family"), Post-graduate thesis, Charokopion University, Faculty of Domestic Economy and Ecology, Athens.

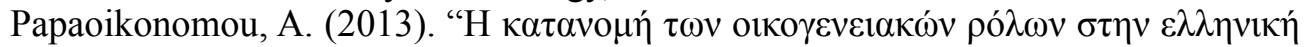

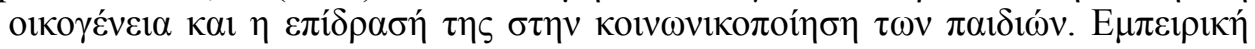
$\pi \rho 0 \sigma \varepsilon ́ \gamma \gamma 1 \sigma \eta$ " ("The division of family roles in the Greek family and its impact on the socialization of children. An empirical approach"). Athens: Ta Ekpaideftika Magazine, issue 107-108.

Sivulka, J. (1998). Soap, Sex and Cigarettes: A Cultural History of American Advertising. Boston: Wandsworth.

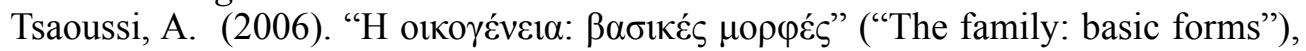
research paper, National and Kapodistrian University of Athens, Faculty of Sociology, Athens. 


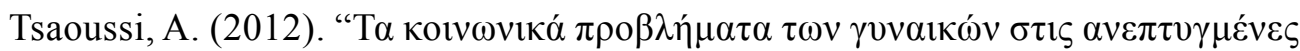
$\chi \omega ́ \rho \varepsilon \varsigma$ " ("The women's social problems in developed countries"), Athens University, Department of Sociology and Gender Relations. http://old.phs. uoa.gr/ ahatzis/SGH08.pdf. Accessed 23 May 2012. .

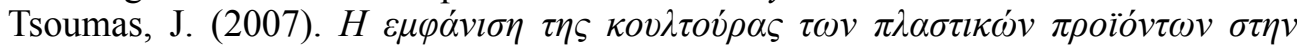

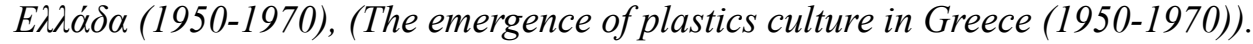
Athens: ION Publications, Athens.

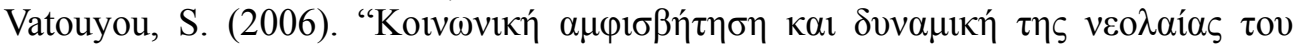

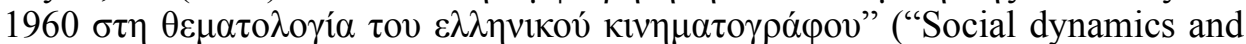
challenge of the 1960's youth as a theme of the Greek cinema"), Proceedings of the A! Conference titled: " 1960 's routes of the young: Political actions, cultural interventions”. Athens: 'Andreas Lentakis' Cultural and Educational Institution.

\section{Endnotes}

1. The largest category of buildings constructed in the major cities of the country (Athens, Thessaloniki, Piraeus) since the early 1950s to the mid 1960s were massive blocks of flats so as to accommodate people who came to these urban centers for work.

2. As during the post-war years a large part of the Greek population was economically and socially impoverished and the state was completely dependent on the U.S. economic aid, the country fully adopted a western- culture which was nothing but a sui generis ideological compilation linking anticommunism, the Greek Orthodox Christian ideal and the American dream. The middle class made then a timid comeback until it became a stable, almost gigantic social net in 1981. This was stimulated by the rise of Andreas Papandreou in power and the farmers, workers, employees and small professionals entrance to the forefront of the political and economic life of the country.

3. The official opening of the Greek television dates on February 23, 1966 to Helen Kypraiou be the first female presenter. Over the years the program of the then E.I. R. (National Foundation of Radio-Television) expanded and in 1969 was connected to the circuit of Eurovision to broadcast the landing of U.S. spacecraft Apollo 12. In 1975, after the political changeover, the state TV was transformed into the organization named ERT (Greek Radio and Television).

4. This female magazine was set up according to the American Life Magazine standards. It soon became its accurate Greek version as it was based on advertising and photography, something that could be witnessed even by its title (Eikones means Images in Greek).

5. We should note that these magazines were particularly in demand in the Greek province where entertainment opportunities were less than in the capital.

6. In the 1960s, the Greek cinema ushered in a period of great prosperity. Several companies were created that raised both the number and the quality of films compared to the international productions of the time. The annual panorama of the Greek Cinema, the Thessaloniki Film Festival, started in 1960. In the same year, Melina Mercouri won the award of the Best actress in the Cannes Film Festival for her performance in the movie "Never on Sunday" and Manos Hadjidakis got the Oscar for the music of the same film. It was the time that the Greek cinema opened its borders and Greek actors became international stars. At the same time it constituted the basic form of entertainment for the majority of the Greek people, and especially those of the province. 
7. The term "Marshall Plan" is associated with the American financial support of many European countries after the Second World War. It was a figment of the postwar US foreign policy and it aimed at halting the prevalence of communism in Europe which would jeopardize the interests of the United States. This is probably why Greek ads both in type and morphology were a little different from other European advertisement models of the time, especially from countries - such as Western Germany, Italy, UK, Portugal, Sweden and so forth - which, along with that financial aid, adopted many American cultural or/and social habits,. This of course meant nothing less than the beginning of cultural globalization which the international community suffered from in the late 20th century. 